\title{
Városarculati megközelítések a 21. századi magyar városok településmarketingjében ${ }^{1}$
}

\section{Approaches to City Branding in the Regional Marketing of 21st-Century Hungarian Cities}

Összefoglalás

A tanulmány a településmarketing viszonylatában értelmezett városarculati szempontokat mutatja be a mai magyar nagy- és középvárosok adottságainak figyelembevételével. A diverz eszmetörténeti felfogások, marketingszisztémák leíró elemzése és összehasonlítása mellett a magyar városhálózat sajátosságait, ok-okozati összefüggéseit is górcsố alá veszi. A tanulmány a kutatási eredményekból kapott helyzetképen túl rávilágít a jelenlegi jogszabályi környezet elméleti és gyakorlati múködésének specifikumaira is.

Journal of Economic Literature (JEL) kódok: D83, M30, N34, O18, R28, R51

Kulcsszavak: településmarketing, városar- culat, urbanizáció, demográfia, kommunikáció

\section{Summary}

The study describes various considerations in city branding interpreted in relation to regional marketing through the characteristics medium-sized and big Hungarian cities. In addition to the analysis and comparison of diverse theories and marketing systems, the characteristics of the Hungarian urban network are described and the cause and effect relationships are revealed. In addition to giving an overview based on the research findings, the study also sheds light on the theoretical and practical specificities in the operation of the current legal environment.

Weninger SÁndor, PHD-hallgató, Nemzeti Közszolgálati Egyetem, Közszervezési és Közigazgatástani Intézet, Közigazgatás-tudományi Doktori Iskola (Weninger.Sandor@uni-nke.hu). 


\section{Tudományos múhely}

Journal of Economic Literature (JEL) codes: D83, M30, N34, O18, R28, R51

Keywords: settlement marketing, city branding, urbanization, demography, communication

\section{Bevezetés}

A városarculat mint fogalom és annak hazai környezetre adaptált, mai keretrendszerben értelmezett használata viszonylag új keletú jelenség, legalábbis közszervezési aspektusból vizsgálva bizonyosan az. A kifejezés fenomenológiailag a vizuális kommunikáció tárgyköréhez kötődik. Ez utóbbit jelen tanulmányban, az egyszerúség kedvéért, a láthatóvá tett gondolat manifesztumaként kezeljük (BálványosSánta, 2003). A vizuális kommunikáció mint megatrend mostani, nagy volumenú térnyerésének okait nehéz lenne pontosan meghatározni, ugyanakkor az elmúlt három évtizedben számos olyan konkrét jelenség volt érzékelhetô, amely előfeltételét képezte, megalapozta vagy legalábbis valószínúsíthetôen befolyásolhatta a jelenlegi helyzet kialakulását.

A Varsói Szerzódés megszúnését (1991) követôen egyrészrôl a rendszerváltás utáni, tranzíciós országok - beleértve Magyarországot is - hirtelen a globalizálódó tốkepiacok látómezejébe kerültek, és ezzel egyúttal - ugyan fokozatosan, de - bekapcsolódtak a globális, nemzetközi kereskedelembe is. Másrészról a Neumann János óta a technológiai szingularitás disztópiájával riogató nézetek is jóval nagyobb visszhangot kaptak, ${ }^{2}$ ugyanis a modern társadalmi berendezkedésból fakadó technológiai felülreprezentáltság rohamléptekben gyorsuló térhódítása jelentôsen átformálta létszervezôdésünket. Az internet okozta információdömping által keltett digitális zaj és információelméleti kontextusban megjelenô redundancia, azok az újabbnál újabb IT-metódusok és szinte kivétel nélkül vizuális megjelenítéssel operáló eszközök, amelyek organikusan beépültek a mindennapjainkba, lassacskán fiziológiai igényeinket is megelôzô, alapvetô létszükségletté avanzsálódtak (Valos et al., 2017).

Tény, hogy ezen fentebb említett szempontokat megkerülhetetlenül szükséges számba venni, ugyanakkor meglátásom szerint a maihoz hasonló, modern városarculat témakörének a honi gyökereit mégis egy jókora idốbeli visszaugrással Budapesten érdemes keresni, méghozzá a 19. század második felében.

A kiegyezés (1867) utáni gazdasági növekedés hatására felgyorsult a városiasodás, a térbeli és strukturális mobilitás, és kibontakozott a magyar társadalom polgári átrétegzôdése. Jóllehet, nem épp ezen szóhasználattal, de jelentéstartalmát tekintve tulajdonképpen a korabeli viszonyoknak megfelelóen, hazai vonatkozásban elôször a dualizmus korában találkozhatunk az épített környezet arculati jelenségeinek urbanisztikai-esztétikai kérdéseivel. Ennek ékes bizonyítékát láthatjuk a Fơvárosi Közmunkák Tanácsának jelentéseit (FKT, 1870-1944) tanulmányozva. Az 1870-tôl múködô testület ${ }^{3}$ városrendezési, üzemeltetési és városfejlesztési tevékenysége mellett, vagy inkább ahhoz kapcsolódóan, a mai értelemben is alkalmazott településképi véleményezési jogkörrel is rendelkezett; így tehát megkerülhetetlenül, városarculati kérdésekkel is foglalatoskodott, még ha ez konkrétan, ily módon éppenséggel nem is volt nevén nevezve, és nem elsôdlegesen a mai értelemben vett kommunikációs célzattal tette mindezt (1870. évi X. tvc.). ${ }^{4}$ 


\section{Tudományos múhely}

Az ARCUlat LEHATÁrolásA A

MARKETINGMODELLEKBEN

A továbbiakban rátérnék a lokalitáshoz mint fizikai és szellemi térhez kötôdố arculat, jelen, településmarketing fókuszú vizsgálódásom szempontjából is releváns, elsôsorban kommunikációs, azon belül is környezeti kommunikációs aspektusban megjelenő, jelenkori megközelítésére.

A Tózsa-Piskóti-féle taxonómia szerinti meghatározást alapul véve: maga a településmarketing egy olyan stratégia (cselekvési program) kidolgozását és megvalósítását jelenti, amelynek során a település irányítói feltárják a település abszolút és komparatív versenyelónyeit, és a lehetséges vevôk felé kommunikálják (Piskóti, 2012; Tózsa, 2014). Felmerül a kérdés, hogy ehhez a városarculat miként kapcsolódik, milyen szerepet tölt be ebben, és egyáltalán hogyan jelenik meg a folyamatban?

A több mint ötven éve termékek és szolgáltatások vonatkozásában sztenderdként hivatkozott, a McCarty-féle 4P-Mix (1960) marketingmodellre (product, price, place, promotion) adaptált elhelyezés során, Tózsa álláspontja szerint, a településmarketing terméke (product) maga a település, aminek az árát (többszintú, komplex és egyedi termék- és szolgáltatáscsomag jellegéból adódóan), a benne élő emberekkel együtt, lehetetlen meghatározni. Tehát az ár (price) fogalmilag nem értelmezhetô, hiszen a várost természetszerúen nem lehet megvenni. Az adásvétel során a település nem változtat helyet (place), így a vevố nem viheti el, sôt az adásvétel alkalmával a tulajdonviszonya sem változik, semmilyen értelemben, ráadásul szimultán többször is eladható. A hangsúly a reklámtevékenységre (pro- motion) helyezódik át, de ez sem hagyományos értelemben vett reklám, hanem marketing, vagyis piacra viteli stratégia. Összességében tehát egy település esetén olyan dolgot kell eladásra „reklámozni”, aminek nincs ára, amire nem jegyezhetô be tulajdonjog, sôt magának az eladás tárgyának definiálása sem egyértelmú, ugyanis az is igen széles spektrumon mozog (Tózsa, 2014).

Fontos kiemelni, hogy az 1960-as évek óta végbement társadalmi-technológiai változások miatt történt a McCarty-féle 4P-Mix továbbfejlesztése. A 7P-Mix három új aspektussal egészült ki, amelyek a promotion szegmenshez köthetően segítették a precíziós elemzómunkát. Ezek név szerint: az emberi tényezók (people), a környezeti és tárgyi elemek (physical evidence), illetve maga a folyamat (process); viszont mindezek ellenére magából a kibôvített csoportosításból sem rajzolódik ki egyértelmúen, hogy egy város tekintetében mi az, ami konkrétan eladható.

Úgy gondolom, hogy a városarculat szerepének és környezeti kommunikációs létjogosultságának megvilágítása során mélyebbre ásva, javasolt megemlítenünk a Kovács által „térérzékeny” marketingmodellnek hívott keretrendszert, ahol háromféle térinterpretációs koncepcióval találkozhatunk. Elsôként a descartes-i alapokon nyugvó, abszolutista („tartályszerú”) térfelfogással. Itt a külsố teret a fizikai létezôk (pl. települések, utak, tereptárgyak stb.) és az abszolút távolságok jellemzik (pl. km). Másodikként a leibnizi felfogáson nyugvó, relacionista (kapcsolati alapú) térfelfogás jelenik meg. Ez tulajdonképpen a kapcsolati hálózatok által meghatározott „belsố terek” világa. Eklatáns példája a közösségimédia-platformok kapcsolati térhálója. A harmadik 
csoportot a Henri Lefebvre és Edward Soja nevéhez köthetô, megélt vagy más néven „harmadik tér” alkotja. Itt a fókusz az adott személy kognitív struktúrájában leképezésre kerüló egyéni térérzetre és térképzetre irányul. Vizsgált kérdései: Nekem „hogy áll össze”? Én hogy látom a teret? Példának okáért, hogy jelenik meg mondjuk egy bevásárlóközpont térszerkezete egy adott vásárló számára? (Kovács A., 2017; Gehl, 2014).

$\mathrm{Az}$ eredeti $4 \mathrm{P}$ modellre visszakanyorodva megemlítendô, hogy annak átdolgozása a Lauterborn-féle 4C modell (1990) (customer wants and needs, cost, convenience, communication). Míg a $4 \mathrm{P}$ a gyártóról szólt, és annak érdekeit vette figyelembe, Lauterborn úgy gondolta, hogy a modern világban inkább a vevô szemszögébôl kell úzni a marketinget (Lauterborn, 1990).

Általánosan megfigyelhetô tehát, hogy a helyhez kötött marketing input-transformation-output modell szerinti lépései során voltaképpen a fizikai vagy földrajzi térben, szellemi vagy kibertérben és ezek speciális hibridjeiben lezajló folyamatokról beszélhetünk (Slack et al., 2010). Ez azért is módfelett lényeges, mert a városarculatnak mindezen aspektusokat szem elôtt tartva, egységes szisztémát kell alkotnia, és reprezentálnia mindezt.

A fentebb ismertetett okfejtés relevanciája a Tózsa-féle értelmezésben is megjelenik. Nála négy nagy területbôl (audit, szegmentáció, imázs, kommunikáció) áll össze a településmarketing intézménye. A meghatározásában kapjuk a legegyértelmúbb választ a fejezet elején feltett kérdésekre: az imázs, vagyis a település arculatának tervezése és kivitelezése tulajdonképpen nem más, mint az auditkor meghatározott készletnek a szegmentáció során meghatározott igényekhez történô igazítása. Ily módon az ezt követố negyedik fázis, a kommunikáció lényegében „csak” az imázs (arculat) megjelenítése, eljuttatása a lehetséges és kiválasztott vevốkörhöz, a célcsoportokhoz (Tózsa, 2014).

Végeredményben ezen keretrendszer szerint az imázs és az arculat ekvivalens „kollokációk”, de összességében egy város tekintetében csak annak hírneve, ami ténylegesen eladható. A hírnév két komponensbốl áll össze. Az egyik a CI (corporation identity), ami nem más, mint maga az arculat; a másik a PR (public relations), ami pedig a település szolgáltatásainak, értékeinek vonzó híre, reklámja, kommunikációja. Ezek a konkrétumok szintjén: a város konkrét szolgáltatásai (oktatási, egészségügyi, szórakoztatási, kereskedelmi, múvelôdési stb.); a város gazdasági és infrastrukturális jellemzối (fóként a szekunder, tercier, kvaterner szektorok tekintetében); a város gazdag, érdekes történelme, múemlékei; a város kultúrája, érdekes hagyományai, rendezvényei; szennyezetlen természeti és társadalmi környezet (tiszta, rendezett település, vállalkozásbarát helyi társadalom, személyés vagyonbiztonság, olcsó és képzett helyi munkaerô); továbbá az információs társadalom városi környezetre adaptált, múködô és fenntartható humánökológiai szisztémái (Ashworth-Voogd, 1997).

\section{MAGYAR VÁROSOK PERSPEKTÍváI, DEMOGRÁFIAI TÉNYEZỐK}

Magyarország lakosságának közel 72\%-a urbánus, azaz városi környezetben él. Ez a szám, értelemszerúen a rurális térségek visszaszorulása mellett, az elmúlt hetven évben tendenciózusan növekedett, és az 
ENSZ becslése alapján 2045-re akár 80\% fölé is mehet (UN, 2018).

Ugyan a jelenlegi, 55\%-os „világátlagot” jócskán meghaladó, európai urbanizáltsági átlaghoz (75\%) képest csak minimálisan vagyunk lemaradva, viszont szembetúnó, hogy míg a magyar városok száma az elmúlt hatvan évben 5,5-szörösére növekedett (1960 és 1990 közötti 30 év alatt 2,6-szorosára, 1990 és 2000 között 1,4-szeresére, 2000 és 2014 között 1,6-szorosára), addig a városi lakosság százalékos mértéke nem lineárisan követte mindezt. Ennek oka egyrészt a rendszerváltást követô közigazgatási újraszervezésben, ${ }^{5}$ illetôleg az EU-s csatlakozás (2004) utáni várossá nyilvánítási hullámban keresendô. Másrészt az is jól kirajzolódik, hogy az 1981-es, 10,7 millió fớt is meghaladó népességcsúcshoz képest ma csaknem 1 millióval kevesebb az ország lakossága, emellett az Enyedi György által is használt Kondratyev-cikluselméletnek a városfejlődés négy fázisára (urbanizáció, szuburbanizáció, dezurbanizáció, reurbanizáció) a gazdasági átstrukturálódások által gyakorolt hatásai is szempontként merülhetnek fel (Enyedi, 2011; KSH, 2015).

Magyarországon a településmarketingból származó bevétel (befektetôk, turisták stb.) elsôsorban Budapestre koncentrálódik, holott Magyarország 9,8 milliós lakosságának csupán 18\%-a (1 749734 fô) él a fôváros közigazgatási határain belül, míg 53\%-a a többi városban, 29\%-a községekben. Budapest, mint számos attribútuma miatt különösen vonzó európai desztináció, domináns erôközpontot képez, meghatároz egyfajta masszív fôváros-pólusosságot. Gyakorlatilag a Budapest-gócpontú (a 67 ezer fôs Érd városát; további $11 \mathrm{db}$, 20-50 ezer fó közötti, csaknem 330 ezer fôs összlakosságú várost; illetôleg számos kisebb települést magában foglaló) több mint hárommilliós Közép-Magyarország régió ${ }^{6}$ kivételével, Magyarország összes régiója konvergenciarégió. Konvergenciarégiónak minôsül minden olyan régió, ahol az egy fő́re jutó GDP kevesebb az EU átlagának 75\%-ánál (EB, 2017).

A városi lakosság értelmezésének viszonylatában kiváltképp fontosnak tartom kiemelni a megyei jogú városi címet. A jelenleg is hatályos Mötv.-t (2011. évi CLXXXIX. törvény Magyarország helyi önkormányzatairól) megelőzően, a helyi önkormányzatokról szóló 1990. évi LXV. törvény alapján megyei jogú várossá nyilvánítását kérhette minden olyan város, amelynek lakossága meghaladta az ötvenezer foót. Ugyanakkor számok tekintetében a mai napig vita van a város és a városias múködés optimumáról (jobbára funkciók, lakosságmennyiség szerinti lehatárolás tekintetében), mivel ez tájegységekként, településmorfológiai szempontokból, továbbá egyedi jellemzókból adódóan meglehetôsen széles spektrumon mozoghat. Azonban kétségtelen az, hogy 50 ezer fôs lakosság felett az önkormányzatoknak a kötelezô feladatellátás és biztosítandó közszolgáltatások mellett - fơként a városok gazdasági teljesítóképességébôl adódóan - már lehetôségük nyílik önként vállalt feladatok formájában, naprakész, pluszszükségleteket is kielégíteni, 21. századi módon és eszközökkel. A városarculat kérdéskörével történô foglalatoskodás, és ehhez kapcsolódóan maga a településmarketing is, tapasztalataim alapján, a gyakorlatban nemritkán ez utóbbi kategóriát erôsíti, habár az Mötv. 13. $§$ (1) bekezdés 13 . pont a helyi adóval, gazdaságszervezéssel és a turizmussal kapcsolatos feladatok ellátását a helyi közügyek, valamint a helyben biztosítható 
közfeladatok körében ellátandó helyi önkormányzati feladatként tünteti fel.

Összesen 23 megyei jogú városunk van. Ezekból 5 az 50 ezer fő alatti (Szekszárd, Salgótarján, Hódmezôvásárhely, Dunaújváros, Nagykanizsa), 11 az 50-100 ezer fó közötti (Eger, Zalaegerszeg, Békéscsaba, Veszprém, Sopron, Kaposvár, Érd, Tatabánya, Szolnok, Szombathely, Székesfehérvár), 6 a 100-200 ezer fó közötti (Kecskemét, Nyíregyháza, Gyôr, Pécs, Miskolc, Szeged), és 1 város éppenhogy meghaladja a 200 ezer fôs lakosságot (Debrecen). Mindent összevetve a 18 $\mathrm{db}, 50$ ezer fó feletti lakossággal rendelkezô városunk a teljes magyar lakosság 18\%-át adja (KSH, 2018).

Törvényszerúség, hogy a legtöbb globalizálódó gazdaságban a munkahelyek növekvố térbeli koncentrációja figyelhetó meg (Nagy, 2010). Hazánkban 1990 után ha nem is drasztikusan, de a településhierarchia felsóbb szintjei felé tolódtak a munkahelyek. 1990-ben a százezer fônél népesebb hazai városokban volt a munkahelyek 38,8\%-a, ami 2011-re 40,7\%-ra emelkedett, míg a százezres városok országon belüli népesedési súlya számottevốn csökkent (Kovács Z., 2017). Ezen szempont azért is különösen számottevô, mivel a településmarketing egyik fố célja a gazdasági teljesítőképesség hatékonyságán keresztül a versenyképesség növelése. A vidéki nagyvárosok esetében számos olyan tényezô megfigyelhetô, amely az önkormányzatok tudatos arculatépítésérôl, kommunkációjáról árulkodik, mely alkalmassá teszi vagy teheti ezen településeket arra, hogy az ország Budapest-pólusosságát dekoncentrálják, vagy legalábbis ezt az éles kontrasztot lágyítsák.

A legnagyobb hazai települések önkormányzatainál közel 90\%-os arányban alkalmaznak kifejezetten kommunikációs munkatársat vagy munkatársakat, az önkormányzatok 52\%-a pedig rendelkezik kommunikációs stratégiával. Ugyanezen településméret-kategória esetében az önkormányzatok közel 80\%-a használja tudatosan a közösségimédia-felületeket, 52\%-uk pedig figyelembe veszi a közösségimédia-felületen érkezô lakossági észrevételeket, panaszokat (Budai-Tózsa, 2018). Ennek relevanciája azért létfontosságú, mert például a legnépszerúbb közösségimédia-felület (Facebook) 2019. elsô negyedéves adatai alapján az látszik, hogy a 743 milliós európai összlakosság (2019-es ENSZ-becslés alapján) csaknem 52\%-a havi szinten aktív felhasználó, míg 286 millió felhasználó, ami a teljes európai lakosság 38\%-a, napi szinten aktív felhasználója a felületnek. Ez az arány európai viszonylatban is kiemelkedô, a hazai 4G-lefedettségnek köszönhetôen Magyarországon akár még magasabb is lehet.

Sarkalatos pontok ezek, hiszen a nemzetközi szakirodalomban uralkodó paradigma szerint a városarculat vizuális kommunikációs vetületének alapos és teljes körú, multidiszciplináris kutatással kapott, valós helyzetképre kell támaszkodnia ahhoz, hogy a grafikai és egyéb dizájntevékenység gördülékenyen és szinergikusan tudjon kapcsolódni a brandépítéshez (Wheeler, 2009). Az elemzett példák alapján úgy túnik, a hazánkban alkalmazott megoldások tartalmi összetételüket illetôen kielégítik ezt a kritériumfeltételt.

\section{HAZAi JOGI ÉS TECHNIKAI VONATKOZÁSOK}

A településfejlesztési koncepcióról, az integrált településfejlesztési stratégiáról és a településrendezési eszközökrôl, vala- 
mint egyes településrendezési sajátos jogintézményekrôl szóló 314/2012. (XI. 8.) Korm. rendelet 2. § 1/a pontja értelmében arculati jellemzó a települési környezet vizuális megjelenését meghatározó jellemzó, amely lehet kulturális, léptékbeli, formai, anyaghasználati (közvetített érzet) és minôségi (stílus). Ezen meghatározás azért kulcsfontosságú, mivel a vizsgálódás fókuszában lévô arculat és arculati kommunikáció tulajdonképpeni alapjait (mondhatni annak „mankóját”) az ország minden településéhez kidolgozandó, településképi arculati kézikönyv és településképi rendelet adják, melyeknek elkészítését a településkép védelmérôl szóló 2016. évi LXXIV. törvény mellett a fentebb idézett 2012-es kormányrendelet írja le és eló.

Érezhetô, hogy a 2012-es jogszabály meghatározása igencsak tág, kis túlzással akár - horribile dictu - pongyolának is nevezhetô, és emellett meglehetôsen szubjektív is; ugyanakkor a jogalkotó szerencsére biztosítja annak lehetôségét, hogy az érintettek akár társadalmi konzultáció formájában, az úgynevezett partnerségi egyeztetés keretében javaslatokat, véleményeket fogalmazhassanak meg. A polgármester - a széles körú társadalmi bevonás és a nyilvánosság biztosítása érdekében - a koncepció, a stratégia, a településrendezési eszközök, a kézikönyv és a településképi rendelet készítése és módosítása során az önkormányzat rendeletében megállapított partnerségi egyeztetés szabályai szerinti helyen és módon tájékoztatja a partnereket, valamint biztosítja számukra a véleményezés lehetôségét. [314/2012. (XI. 8.) Korm. rendelet 29/A. § (1) bekezdés.] Mindez a gyakorlatban a lakosság, az érdekképviseleti szervek, a civil és gazdálkodási szer- vek, egyéb ernyôszervezetek, illetôleg a vallási közösségek bevonását jelenti, alapelvként a helyi adottságoknak megfelelô, teljes körú nyilvánosság biztosítása mellett (Miniszterelnökség, 2017).

Mint az látható, a településmarketinget maga a jogalkotó is kompetenciamarketingként értelmezi, azaz a feladat ellátása elsôsorban az önkormányzat hatáskörébe tartozik. Ennek legfőbb oka és logikája, hogy egy helyi vállalkozóval vagy érdekcsoporttal ellentétben, akik akár valótlanságokat is állíthatnak a sikeres üzletvitel érdekében, az önkormányzat, mint a független, lokális közigazgatás megtestesítője, a helyi hatóság képviselôje, a magán- vagy üzleti szférához viszonyítottan jóval nagyobb fokú (köz) bizalmat élvez, szavahihetô, „kompetens” szereplőnek minôsül (Tózsa, 2014).

A fentebb hivatkozott dokumentumok megalkotásának fontos és kiemelendó komponense, hogy elkészítésük és monitorozásuk komoly és folyamatos szakmai támogatás és felügyelet mellett zajlik. A településképi arculati kézikönyvek és településképi rendeletek digitális egyeztetési honlapját ${ }^{8}$ a Miniszterelnökség Építészeti és Építésügyi Helyettes Államtitkárság, Területrendezési és Településügyi Fóosztálya megbízásából a Lechner Tudásközpont üzemelteti, ugyancsak a vonatkozó 2012-es kormányrendelet alapján. Ezen felület biztosítja a kidolgozásért felelôs szervnek az elkészült kézikönyv és a településképi rendelet feltöltését, továbbá a vélemények elérését; illetôleg a véleményezốk számára a kézikönyv és a rendelet elérhetôségét és a véleményezés lehetôségét. Az elkészült kézikönyvet a polgármester megküldi véleményezésre a Magyar Építész Kamarának, a Nemzeti Média- és Hírközlési Hatóságnak, 


\section{Tudományos múhely}

a kulturális örökség védelméért felelôs miniszternek és az illetékes nemzeti park igazgatóságának; míg a településképi rendeletet az állami fóépítészi hatáskörében eljáró fốvárosi és megyei kormányhivatalnak, a Nemzeti Média- és Hírközlési Hatóságnak, a kulturális örökség védelméért felelôs miniszternek és az illetékes nemzeti park igazgatóságának kell hogy eljuttassa. Ezt követốn a meghatározott szervek véleményezik azt. ${ }^{9}$

Szintén a 2012-es kormányrendelet tartalmaz egy irányadó ajánlást, kvázi útmutatót az arculati kézikönyv tartalmát illetôen: a bevezetés, köszöntố után legelôször a település bemutatása, általános településkép megjelenítése, településkarakter ismertetése esedékes. Ezt követôen az úgynevezett örökség, vagyis a településképi szempontból meghatározó építészeti, múemléki, táji és természeti értékek, településképi jellemzốk taglalása; majd a településképi szempontból meghatározó, eltérố karakterú területek lehatárolása, a településképi arculati jellemzók és a településkarakter bemutatása következik. Mindezek tükrében folytatólagosan a településkép minôségi formálására vonatkozó ajánlások: építészeti útmutató, közterületek településképi útmutatója, utcák, terek, közparkok, közkertek; majd jó példák bemutatása: épületek, építészeti részletek (ajtók, ablakok, tornácok, anyaghasználat, színek, homlokzatképzés), kerítések, kertek, zöldfelületek kialakítása, sajátos építményfajták, reklámhordozók, egyéb múszaki berendezések. Végül a beépítési vázlatok mint opcionális tartalom [314/2012. (XI. 8.) Korm. rendelet 12. melléklete].

Mivel egy települési arculati kézikönyv terjedelme az adott város méretének és jellegének függvényében akár több száz oldalra is rúghat (ahogy azt láthatjuk Pécs 310, Szeged 224, Székesfehérvár 219, vagy Debrecen 184 oldala esetében is), így a könnyebb áttekinthetôség kedvéért az egyik legkisebb területú (259 ha) és lakosságszámú (25 800 fô) budapesti kerület mindössze 35 oldalas városarculati kézikönyvének néhány kiragadott példáján keresztül igyekszem illusztrálni a dokumentum sajátosságait.

A górcsô alá vett Budapest Belváros-Lipótváros V. Kerületi Önkormányzat városarculati kézikönyvének konkrét rendelkezéseit megvizsgálva jól érzékelhetô, hogy a kerület - fốként frekventáltságából és kiemelkedô történelmi-építészeti örökségéboól adódóan - különösen nagy jelentőséget tulajdonít karakterisztikus városképi, városarculati megjelenítésének, és mindent megtesz annak megórzése érdekében. A kézikönyv elôírásait a kerület, három másik vonatkozó önkormányzati rendelet figyelembevételével, azok kiegészítéseként, együtt alkalmazza. Ezek nevesítve: az önkormányzat tulajdonában lévô közterületek használatáról és rendjérôl szóló, a településképi bejelentési eljárásról és településképi kötelezésról szóló, illetôleg a kerületi városrendezési és építési szabályzatáról és szabályozási tervérôl szóló önkormányzati rendeletek.

Vizuális megjelenés szempontjából a dokumentum értelmezésében az utcák három arculati kategóriája (kortárs arculat; klasszikus, történelmi arculat; vegyes arculat) megfelelően elkülöníthetô, precedensekkel alátámasztott, egzakt csoportokat alkot. Mindhárom arculati profil esetében az útpálya, a parkolósáv, a gyalogosfelületek burkolatai, azok dimenziói, a terek meghatározó stílusjegyeit hordozó elemek (pl. lámpatest-kandeláber, hulladékgyújtố, pad, utcabútor stb.) részlete- 


\section{Tudományos múhely}

sen szerepelnek. Szintén helyspecifikus sajátosság, hogy a kerület külön figyelmet fordít a vendéglátóhelyek szezonális kitelepülésekor jelentkezô, idôszakos közterület-használat arculati megjelenést érintô, aprólékos szabályozására. Itt felsorolják a különféle mobil emelvényeket, teraszokat, pódiumokat, térfalakat és ezek kialakításának, elhelyezésének rendjét; továbbá olyan akkurátus szempontokat is dokumentálnak, mint az utcák szintjén kötelezôen egységes veremrácsos vagy rögzített gyöngykavicsos felülettel borítandó favermek. Emellett önálló kitételként találkozhatunk például az árnyékolószerkezetek alkalmazási megkötéseinek taglalásával is: olyan kritériumok fogalmazódnak meg, mint a környezethez illeszkedó kivitel, vagy az anyaghasználatra történố ajánlások ismertetése. Kulcsfontosságú megemlíteni, hogy az arculati kézikönyvek útmutatásai általában meglehetôsen rigorózus álláspontot képviselnek a közterületi funkciók kérdését illetôen. Ezen dokumentum hasábjain is - az aktuális környezetre adaptálva, de - egyértelmúen tetten érhetô, hogy a közterületi funkciók tervezése kapcsán a funkciók szerinti arculatváltás-tervezés nem támogatott, azaz a kitelepülési lehetôségek burkolati megkülönböztetése nem elfogadható (Belváros-Lipótváros V. Kerületi Önkormányzat, 2015).

\section{ÖssZEFogLALÁs}

Mindent összevetve elmondható, hogy az elmúlt 7-8 évben a magyar közép- és nagyvárosok elól szinte az összes olyan akadály elhárult, amely hátráltatta ôket, hogy sikeres marketingtevékenységet folytassanak, és megpróbálják dekoncentrálni az ország fốváros-pólusosságát. Meglátásom szerint a bemutatott szempontok számos olyan lehetôséget kínálnak, amelyek akár operatív, esetleg stratégiai dimenziókban elôsegíthetik ezen tudományos igényességgel végzett szakmai munka eredményességét a településmarketing területén.

\section{JEGYZETEK}

1 A tanulmány az Emberi Erôforrások Minisztériuma ÚNKP-18-3-I-NKE-102 kódszámú Új Nemzeti Kiválóság Programjának támogatásával készült.

2 I. J. Good a 1960-as években fejlesztette tovább és publikálta Neumann nézetein alapuló elméleteit, majd Vernor Vinge: The Coming Technological Singularity: How to Survive in the Post-Human Era (1993) címú esszéje, illetôleg Raymond Kurzweil írásai élezték ki a tudományos diskurzust a témában.

3 Annak ellenére, hogy Buda és Pest egyesítése az 1872. évi XXXVI. törvénycikk elfogadásával (1872. évi XXXVI. törvénycikk Buda-Pest fôvárosi törvényhatóság alakitásáról és rendezésérôl), 1873. január 1-jei hatállyal emelkedett jogerôre, az 1870-1871-es jelentésekben a fóváros rendre Budapest elnevezéssel szerepel.

4 1870. évi X. törvénycikk a Duna-folyamnak a fốváros mellett szabályozásáról s a forgalom és közlekedés érdekében Buda-Pesten létesitendő egyéb közmunkák költségeinek fedezésérôl és e közmunkák végrehajtási közegeirôl. https:// web.archive.org/web/20130420114133/http:/ / www. 1000 ev.hu/index.php?a=3\&param $=5416$.

5 A 1989-es rendszerváltó évben 40 községból lett város, kvázi „kárpótlás” gyanánt (Kovács Z., 2017).

6 A térségen jól megfigyelhetô a kétezes években felélénkülô dezurbanizáció, illetve a szétterülés, az úgynevezett „urban sprawl” jelensége; a városok körül szabályozatlanul, külsố kontroll nélkül ment végbe ez a terjeszkedés, jelentôs feszültségeket gerjesztve. A budapesti agglomeráció nyolcvan településén a lakás-, gazdasági és szabadidôs célokra szolgáló felszín kiterjedése 1959 és 2014 között 180-ról 411 négyzetkilométerre nôtt (Kovács Z., 2017).

7 Sem a 1990. évi LXV. törvény, sem az Mötv. nem rendelkezett arról, hogy a megyei jogú városi címet el lehetne veszíteni, így Dunaújváros, Hódmezôvásárhely és Nagykanizsa, bár nem megyeszékhelyek, és népességük már nem éri el az 50 ezer fôt, továbbra is viselhetik ezt a címet. 


\section{Tudományos múhely}

8 www.e-epites.hu/tak.

9 http://tak.lechnerkozpont.hu.

\section{FelHaSZnÁlt IRODALOM}

Ashworth, Greg J. - Voogd, Henk (1997): A város értékesítése. Közgazdasági és Jogi Könyvkiadó, Budapest.

Bálványos Huba - Sánta László (2003): Vizuális megismerés, vizuális kommunikáció. Balassi Kiadó, Budapest.

Belváros-Lipótváros V. Kerületi Önkormányzat (2015): Városarculati Kézikönyv. 275/2015. (XII.10.) B-L.Ö. határozat, www.belvaros-lipotvaros.hu/_user/browser/File/2015/ V\%C3\%A 1 rosarculati $\% 20 \mathrm{k} \% \mathrm{C} 3 \% \mathrm{~A}$ 9zik\%C3\%B6nyv.pdf.

Budai Balázs Benjámin - Tózsa István (2018): KÖFOP-2.3.4-VEKOP-15-2016-00002 „Önkormányzati Fejlesztések Figyelemmel Kísérése II.” Önkormányzatok információfeldolgozási képességeit (pl. fejlesztési, tervezési, együttmüködési, módszertani stb.) szükségleteit és a továbblépés lehetôségeit meghatározó kutatás. Kutatási Jelentés, Belügyminisztérium Önkormányzati Koordinációs Iroda, Budapest.

Enyedi György (2011): A városnövekedés szakaszai újragondolva. Tér és Társadalom, 25. évf., 1. sz., 5-19.

EB (2017): Az én régióm, az én Európám, a mi jövônk. Hetedik jelentés a gazdasági, társadalmi és területi kohézióról. Európai Bizottság, Regionális és Várospolitikai Főigazgatóság, https:/ / ec.europa. $\mathrm{eu/regional \_ policy/sources/docoffic/offi-}$ cial/reports/cohesion $7 / 7 \mathrm{cr} \_$hu.pdf.

FKT (1870-1944): Fớvárosi Közmunkák Tanácsa hivatalos jelentései, 1870-1944. Fôvárosi Szabó Ervin Könyvtár, https://library.hungaricana. $\mathrm{hu} / \mathrm{hu} /$ collection/fszek_kozmunkaktanacsa.

Gehl, Jan (2014): Élhetố városok. Terc Kiadó, Budapest.

Kovács András (2017): Egy „tér-érzékeny” marketing modell bemutatása. MRTT Vándorgyúlés, https:// doi.org/ 10.13140/RG.2.2.36711.34722/1
Kovács Zoltán (2017): Városok és urbanizációs kihívások Magyarországon. Magyar Tudomány, 178. évf., 3. sz., www.matud.iif.hu/2017/03/06. htm\#1tb.

KSH (2015): Magyarország településhálózata 2. Városok-falvak. Központi Statisztikai Hivatal, Budapest, www.ksh.hu/docs/hun/xftp/idoszaki/ mo_telepuleshalozata/varosok_falvak.pdf.

KSH (2018): Magyarország közigazgatási helynévkönyve. Központi Statisztikai Hivatal, Budapest, www.ksh.hu/docs/hun/hnk/hnk_2018.pdf.

Lauterborn, Bob (1990): New Marketing Litany: Four P's Passe: C-Words Take Over. Advertising Age, Vol. 61, No. 4.

Miniszterelnökség, Építészeti és Építésügyi Helyettes Államtitkárság (2017): A településképi arculati kézikönyvek elkészitése, a településkép védelmérôl szóló 2016. évi LXXIV. törvény végrehajtása során. Szakmai segédlet, www.kormany.hu/download/b/6a/f0000/TAK_oktat\%C3\%B3_j.pdf.

Nagy Gábor (2010): A világgazdaság és a globális munkaerôpiac. In: Mészáros Rezsố et al. (szerk.): A globális gazdaság földrajzi dimenziói. Akadémiai Kiadó, Budapest, 229-248.

Piskóti István (2012): Régió- és településmarketing. Marketingorientált fejlesztés, márkázás. Akadémiai Kiadó, Budapest.

Slack, Nigel - Chambers, Stuart - Johnston, Robert (2010): Operations Management. Financial Times Prentice Hall, New York.

Tózsa István (2014): Turizmus és településmarketing. BCE Gazdaságföldrajz és Jövôkutatás Tanszék, Budapest.

UN (2018): World Urbanization Prospects. The 2018 Revision. United Nations.

Valos, Michael J. - Maplestone, Vanya L. - Polonsky, Michael J. - Ewing, Mike (2017): Integrating Social Media within an integrated Marketing Communication Decision-Making Framework. Journal of Marketing Management, Vol. 33, No. 17-18, https://doi.org/10.1080/ 0267257X.2017.1410211.

Wheeler, Alina (2009): Designing Brand Identity: An Essential Guide for the Whole Branding Team. John Wiley \& Sons, New Jersey. 